\title{
Energy efficiency opportunities in Hotels
}

\author{
Dina M.Said, Kamelia Youssef and Hatem Waheed \\ Egyptera, Cairo, Egypt \\ dinasaid88@yahoo.com, k_energystorm@yahoo.com, \\ hatem.waheed@hotmail.com
}

\begin{abstract}
According to the statistics in Egypt (2013), the number of hotels is 1193 , about 407 of them have contracted power greater than $500 \mathrm{~kW}$.
\end{abstract}

Air conditioning, lighting, water heating and refrigeration represent the main activities demanding electrical energy in hotel business.

The energy consumption per night spend changes a lot, depending on various factors; facilities provided, category of hotel, occupancy, geographical situation, weather conditions, nationality of clients, design and control of the installations.

Energy benchmarking is an internal management tool designed to provide ongoing, reliable and verifiable tracking on the hotels performance. The most useful performance indicator (or Energy Efficiency Benchmarking) of hotels are: Lighting Power Density (LPD) in W (for lighting)/m2, and energy intensity $(\mathrm{kWh} / \mathrm{m} 2 / \mathrm{y})$.

There are multiple benefits for improving energy in hotel business; reduces the hotel's operating cost, reduces climate change risks and promotes green tourism.

Energy efficiency opportunities are low-cost measures and cost- effective investments.

There are many energy saving opportunities for lighting in hotel's guest rooms as well as the more obvious savings in lobbies and exterior lighting areas. Behavior campaigns can yield substantial energy savings, both through the guests and housekeeper behavior. Encouraging housekeepers to use natural light during room cleaning is a simple first step to implement energy saving program.

This paper presents the energy efficiency guidelines and energy benchmarking for hotels. Also a case study showing how the energy efficiency program implemented is presented.

\section{OVERVIEW OF ENERGY CONSUMING ACTIVITIES IN A HOTEL}

The main energy consuming activities in a hotel are:

- Heating rooms.

- Cooling rooms.

- Lighting.

- Hot water use and other energy consuming activities by guests.

- Preparing meals.

- Swimming pools.

- Others.

Table (1) represents consumption structure of a hotel.

Table 1. ENERGY CONSUMPTION STRUCTURE OF A HOTEL [6]

\begin{tabular}{|c|c|}
\hline Type of load & Energy consumption (\%) \\
\hline Cooling source & $14.2 \%$ \\
\hline Heating source & $10.7 \%$ \\
\hline Fan & $15.7 \%$ \\
\hline Water & $2.9 \%$ \\
\hline Hot water supply & $9.9 \%$ \\
\hline Lighting & $14.7 \%$ \\
\hline Outlet & $7.7 \%$ \\
\hline Others & $24.2 \%$ \\
\hline
\end{tabular}

\section{ENERGY EFFICIENCY}

- uses less energy to perform the same tasks and functions

- saves energy.

- lowers operational costs.

- reduces carbon emissions/foot print.

- increases competitiveness.

Table (2) classified use to EE 
Table 2. CLASSIFICATION USED TO EE

\begin{tabular}{|c|c|}
\hline Item & Classification \\
\hline $\begin{array}{c}\text { Energy } \\
\text { management }\end{array}$ & $\begin{array}{c}\text { - assess energy profile. } \\
\text { - draws up a simple energy policy. } \\
\text { - ensures periodic serving and maintenance of } \\
\text { equipment and device. }\end{array}$ \\
\hline $\begin{array}{c}\text { Reduction of } \\
\text { the Hotels' } \\
\text { heating and } \\
\text { cooling } \\
\text { needs }\end{array}$ & $\begin{array}{r}\text { - provide information to staff and guests. } \\
\text { - protects the building from the summer heat. } \\
\text { Equipment } \\
\text { efficiency }\end{array}$ \\
\hline
\end{tabular}

\section{ENERGY EFFICIENCY OPPORTUNITIES}

EE provides hotel owners and operators cost savings. Efficiency also improves the service of capital equipment, enhances guest comfort, and demonstrates a commitment to climate stewardship.

In a typical hotel, lighting, air conditioning and water heating represent up to $70 \%$ of total energy consumption. Laundry is considered as one of the largest consumption segment of electrical power in hotels.

The following shows a guide on how to reduce energy consumption with low cost procedures or no cost at all sometimes.

\section{A. Laundry EE opportunities}

- Washing machines shouldn't be during peak hours and it is best to operate them only when in full loads.

- Use high efficiency appliances (such as washing machines, dryers, steam irons etc.) and other high-efficiency equipment to minimize electricity consumption.

- Reduce the temperature of water used for laundry from $85^{\circ} \mathrm{C}$ to $60^{\circ} \mathrm{C}$, or use cold water washing when possible. It will save energy and cut down on costs.

- Make sure that washing machines and dryers are kept clean and have no scale.
- Turn off lights, ventilation and air conditioning when the area is not being used.

\section{B. Lobby and other hotel areas EE opportunities}

- Install LEDs in the lobby area and around the hotel.

- $\quad$ Set the temperature in busy areas of the hotel at $24^{\circ} \mathrm{C}$.

- Switch off or dim lights in areas that receive natural sunlight during the day.

- All light fittings in the hotel should be cleaned on a regular basis.

- Install occupancy sensors for lighting in areas such as rooms that are not regularly used such as meeting rooms or storage areas, or walkways/corridors.

- Some elevators can be programmed to stay stationary on the floor they exit at instead of all elevators returning to the lobby.

- During off-peak periods shut down one or two of your elevators to help save energy.

- Heating of pools can be quite costly. Try to maintain the temperature of the pool to $25.5^{\circ} \mathrm{C}$

- Install Light Emitting Diodes (LED) in areas where the lighting is on continuously or for long periods, e.g. exit signs, other signs, stairwells, front desk etc.

- Install electricity meters in each department to monitor consumption.

- Operate garden and exterior lights only when there isn't enough natural light.

- Turn off exterior decorative lights in the middle of the night when most guests are asleep.

- At the end of the workday, make sure that lights, air conditioning and office equipment is switched off in the hotel's back-of-house areas. 
- Make sure equipment is used efficiently in the hotel's office areas. E.g. Copiers, fax machines, computers, printers etc.

\section{KITCHENS / RESTAURANTS / COFFEE SHOPS EE opportunities}

- Use gas ovens rather than electrical ones if possible.

- Lights in areas such as coffee shops and restaurants should have flexible or separate switches so that part of the lighting system can be switched off if that area is not being used. Another good idea is to install dimmers.

- Keep the walls and ceilings of the restaurants clean for better light reflection.

- Use high efficiency appliances (such as fridges, freezers, dishwashers, etc.) and other highefficiency equipment to minimize electricity consumption.

- Switch off and unplug all appliances after their use (coffee makers, mixers, blenders, grills, fryers, plate warmers, stoves etc.). Electricity to power appliances and electronics are still consumed while the devices are turned off, so make sure they are unplugged.

- Make sure all kitchen equipment and appliances are cleaned and checked daily.

- Turn off exhaust fans and lights when the kitchen is not being used.

- Keep the refrigerator full if possible.

- Do not put items right in front of the refrigerant coils or fans in a way that would restrict air circulation.

- Try using minimum number of electrical appliances; avoid using them all simultaneously, especially during peak hours.

\section{Guest rooms EE Opportunities}

- Install efficient air conditioning units.

- Set room temperature to $24^{\circ} \mathrm{C}$.
- Set unused room temperature to $28^{\circ} \mathrm{C}$ or switch them off completely.

- Install lighting emitting diodes (LEDs) in all rooms; LEDs use about $10-15 \%$ of the energy and last up to 25 times longer than regular incandescent bulbs.

- Install master key-tag switches at the entrance of each guest room, which is activated by a room key tag/card. When guests leave the room and remove the key tag from the holder (master switch), lighting, heating, ACs, radio and television are automatically switched off. Energy management systems such as this can reduce the electricity consumption of guest rooms by 15 to $30 \%$.

- Close the blinds or drapes in unoccupied rooms.

- Make sure windows are tightly shut to minimize air escaping.

- Clean lamps and lamp shades regularly.

- $\quad$ Set the temperature of water heaters between 49 and $55^{\circ} \mathrm{C}$.

- Avoid keeping equipment such as televisions, hair dryers, and lamps close to $A / C$ thermostats. The heat from these appliances can affect the thermostat readings and increase energy consumption.

- Provide regular preventive maintenance to all appliances, boilers, piping and other equipment.

\section{PILOT PROJECT (“Z” HOTEL)}

Before energy use can be reduced in the hotel, it is necessary to understand how energy is being consumed. It is also helpful to compare the hotel's energy consumption to other similar hotels. It's very important to know how efficient is the hotel in terms of energy and where potential energy saving could be made through energy conservation.

" $Z$ " hotel building mainly consumes its energy on water heating, space heating, refrigeration, space cooling, cooking, lighting and other building services. 
The Z-hotel has166 normal guest rooms, 7 suite rooms and 4 conference rooms. The annual energy consumption for the year 2012 is equal to 573,000 $\mathrm{KWh}$

Table (3) Shows electric loads in hotel as result of energy audit.

Table 3. KW FOR APPLIANCES IN HOTEL

\begin{tabular}{|c|c|}
\hline Place & Power for appliances (kW) \\
\hline Guest rooms & $1.764 /$ guest room \\
\hline Suite rooms & $1.963 /$ suite room \\
\hline 4 Conference rooms & 12.97 \\
\hline Bazar & 0.125 \\
\hline Laundry & 33.476 \\
\hline Kitchen & 22.98 \\
\hline Restaurant & 2.36 \\
\hline
\end{tabular}

The appliances (electrical loads) are: lamps, TV, mini bars, hair dryers, washing machines, dryers, irons, fans, ACs, refrigerators and kitchen machines (coffee maker, meat blinder, toaster, ...).

\section{TYPES OF LAMPS AND RATING}

Different rating and type of lamps are used. Table (4) shows the result of audit

Table 4. TYPE AND RATING OF LAMPS

\begin{tabular}{|c|c|}
\hline Type of Lamp & Rating (W) \\
\hline CFLs & $11 \& 22$ \\
\hline Fluorescent lamp (T12) & $20 \& 40$ \\
\hline Incandescent lamps & $40 \& 60 \& 100$ \\
\hline Halogen lamp & 25 \\
\hline LED lamp & $3 \& 6$ \\
\hline
\end{tabular}

Energy performance benchmarking is an internal management tool designed to provide ongoing, reliable and verifiable tracking on the hotels performance. The most useful performance indicator (or Energy Efficiency Benchmarking) of hotels is: Lighting Power Density (LPD) in W (for lighting)/m2.

Table (5) shows the calculated LPD for different places in hotel, and LPD according to ASHRAE/ IENSA standard [1].

From Table (5) it is noticeable that the LPD for conference rooms, laundry, kitchen and restaurant is exceeding the standard value. Then a use of high efficiency fluorescent lamps and electronic ballasts in such area, which is used for long hours, would greatly improve both efficacy and LPD.
Table 5. EE BENCHMARKING FOR DIFFERENT PLACE IN HOTEL.

\begin{tabular}{|c|c|c|}
\hline Place & $\begin{array}{c}\text { Calculated LPD } \\
\text { (w/ m2) }\end{array}$ & $\begin{array}{c}\text { ASHRAE/IENSA(1) } \\
\text { LPD (w/ m2) }\end{array}$ \\
\hline Guest room & 4.125 & 11 \\
\hline Suite room & 4.95 & 11 \\
\hline Conference room & 27.59 & 13 \\
\hline Bazar & 13.44 & 14 \\
\hline Laundry & 22.625 & 5 \\
\hline Kitchen & 24 & 12 \\
\hline Restaurant & 14.15 & 13 \\
\hline
\end{tabular}

According to [5] the guest room energy benchmark figures are represented in Table (6).

Table 6. KWH PER OCCUPIED GUEST ROOM PER YEAR

\begin{tabular}{|c|c|c|c|}
\hline EE rating & Good & Fair & Poor \\
\hline Electricity $\mathrm{kWh} /$ room & $<1825$ & $1825-2550$ & $>2550$ \\
\hline
\end{tabular}

The guest room energy benchmark for " $Z$ " hotel is $3312 \mathrm{kWh} / \mathrm{room} / \mathrm{y}$.

\section{CONCLUSION}

Energy is essential to maintain comfort standards in a hotel; however it is important that this energy is used efficiently. Reducing the energy consumption in hotels helps in environmental protection by reducing greenhouse gas emissions.

EE in hotel is a valuable resource that creates a winwin solution on multiple fronts. It saves energy consumers, money, increases comfort, protects the environment and enhances the economy. When EE is mixed with smart energy practices, like turning off lights, air conditioners, and TVs that are not in use, all of the benefits above are compounded. Providing training to all hotel staff on EE is important to motivate for energy saving.

\section{REFERENCES}

[1] ASHRAE/IESNA standard 90.1 Space-by-space method.

[2] Evaluation of energy Consumption in Mediterranean island.

Hotels: Case study: The Balearic Islands Hotels A.Mota-Pol, Michals Karagiorgas Barcelona, Spain.

[3] Hotels: An overview of energy use and energy efficiency opportunities energystar.gov. 
Renewable Energy and Sustainable Development (RESD) Volume 3 Issue 1, Special Issue, March 2017 - ISSN 2356-8569 http://dx.doi.org/10.21622/RESD.2017.03.1.099

[4] Hotel Design and Energy Consumption Bin Su World Academy of Science, Engineering and Technology 722012

[5] Energy Efficiency in hospitality Industry Mr.Pawa Kumar

National Productivity Council, New Delhi.
[6] Energy Conservation for Hotels Major points, measures, and successful cases of energy conservation for hotels The energy conservation center, Japan. 